GLOBAL DEVELOPMENT AND ENVIRONMENT INSTITUTE

WORKING PAPER No. 09-01

\title{
Resources, Rules and International Political Economy: The Politics of Development in the WTO
}

\author{
Kenneth C. Shadlen
}

January 2009

This paper will be published as a chapter in Sarah Joseph, David Kinley and Jeff Waincymer, ed., WTO and Human Rights: Interdisciplinary Perspectives (Edward Elgar, 2009)

Tufts University

Medford MA 02155, USA

http://ase.tufts.edu/gdae 


\begin{abstract}
This paper examines the contemporary politics of intellectual property (IP) and investment in the World Trade Organization (WTO). I examine the underlying and perennial conflicts that pit developing and developed countries against each other in these two areas and the nature of the two agreements reached during the Uruguay Round, the Agreement on Trade-Related Aspects of Intellectual Property Rights (TRIPS) and the Agreement on Trade-Related Investment Measures (TRIMS). I then analyze developed countries' efforts to push beyond the TRIPS and TRIMS agreements, and, critically, developing countries' success in forestalling these efforts. Developing countries have "prevailed" in the current international conflicts over IP and investment not by securing rules that they desire, but rather by preventing the imposition of arrangements that they regard as worse than the WTO status quo.

To understand how weak countries have managed to overcome developed countries' IP- and investment-related campaigns and thus prevail (even in the qualified sense) in an important international setting like the WTO, I draw on the insights from two approaches to the study of international political economy (IPE), structuralism and institutionalism. The structuralist approach focuses on the distribution of resources as the key determinant for explaining international outcomes, while the institutionalist approach focuses on the effects of rules. What we see is that, within a broad set of constraints that is determined by the distribution of resources, the rules of the WTO drive the outcomes. In particular, the WTO's rules of unweighted voting and consensus decision-making have inflated developing countries' influence in the post-Uruguay Round setting and allowed them to block the efforts of wealthier countries to impose new constraints on national policy in the areas of IP and investment. In the concluding section I address a subsequent question that logically follows from the analysis: why, if developing countries can block developed countries' initiatives now were they unable to do so during the Uruguay Round?
\end{abstract}




\title{
Resources, Rules and International Political Economy: The Politics of Development in the WTO
}

\author{
Kenneth C. Shadlen*
}

\section{Introduction}

The Uruguay Round of multilateral trade negotiations, which began in 1986 and concluded with the signing of the "Final Act" in 1994, marked a watershed in the making of the international political economy. In addition to giving birth to a new international organization, the World Trade Organization (WTO), the Uruguay Round introduced binding agreements in new areas that had previously been left out of the international trading regime. That is, while the WTO’s predecessor organization, the General Agreement on Tariffs and Trade (GATT), addressed national policies in tariffs and nontariff trade measures, the Uruguay Round addresses policies in a variety of "traderelated” activities, such as intellectual property (IP) and investment.

The broadening of the international trade regime to include binding constraints in these new issue areas was fiercely resisted by many developing countries. Yet, despite their resistance to negotiating IP and investment, and the unfavourable nature of the subsequent agreements, developing countries accepted the final outcome. Developed countries' insistence that the Uruguay Round be an all or nothing affair — a "single undertaking"-meant that developing countries could not approve the Final Act, with its promises of increased access to North American and European markets, the final elimination of the onerous Multi-Fiber Arrangement, and the establishment of a more useful system for dispute resolution, without also accepting agreements that imposed new multilateral disciplines on IP and investment (along with other areas, such as services and subsidies and so on).

In the period after the Uruguay Round, the "North-South" conflicts over IP and investment remain politically charged. Developed countries have sought to secure commitments beyond that stipulated by the WTO. In both policy areas, developed countries were unsatisfied with the settlements reached in the Uruguay Round and sought to impose additional limitations on developing countries' policy options. And in both policy areas developing countries adamantly resisted and successfully turned back these efforts.

How have weak countries managed to prevail in an important international setting like WTO? To address this question I draw on the insights from two approaches to the

\footnotetext{
* I wish to thank the participants at the June 2007 conference at Monash University's Prato Centre for their helpful comments on my presentation, and to Jeff Waincymer for insightful and constructive feedback on an earlier draft of this chapter.
} 
study of international political economy (IPE), structuralism and institutionalism. The structuralist approach focuses on the distribution of resources as the key determinant for explaining international outcomes, while the institutionalist approach focuses on the effects of rules. What we see is that, within a broad set of constraints that is determined by the distribution of resources, the rules of the WTO drive the outcomes. In particular, the WTO's rules of unweighted voting and consensus decision-making have inflated developing countries' influence in the post-Uruguay Round setting and allowed them to block the efforts of wealthier countries to impose new constraints on national policy in the areas of IP and investment.

In the second section of the chapter I present these two analytic approaches to the study of IPE, deriving a set of expectations about North-South relations. In sections three and four I consider the North-South politics of IP and investment, respectively, both in the Uruguay Round and the post-Uruguay Round period. These issue areas are marked by endemic and underlying sources of conflict, which I highlight in each instance. In both cases we see developing countries blocking developed countries' efforts to impose new international regulations, and in both instances the power that allows developing countries" to "prevail"" is derived from rules and not resources. In the fifth and concluding section, I summarize the findings and I address a subsequent question that logically follows from the analysis: why, if developing countries can block developed countries' initiatives now were they unable to do so during the Uruguay Round?

Before proceeding, a caveat is in order. Throughout the chapter I refer to "developed” and "developing” countries, and I treat them as homogenous blocks. Doing so is problematic, to say the least, and invites criticisms from all corners. To be sure, not all wealthy countries share the same interests on all issues and nor do all poorer countries; plenty of issues in the international political economy - and even the WTO are marked by cross-cutting alliances where some coalitions of developed and developing countries are pitted against other coalitions of developed and developing countries. Notwithstanding these observations, it is also true that there exist certain underlying cleavages in the international political economy that are based on income - that countries of different levels of economic development are likely to have different interests in the regulation of the international political economy and, these differences are the source of persistent and endemic conflict. Indeed, an examination of the politics of the post-World War II international trading system leaves the undeniable sense that the "North-South" cleavage has been - and continues to be - a prevailing axis of conflict. ${ }^{2}$

\section{Resources, Rules, and North-South Conflict}

Traditionally the field of IPE has been organized around the topic of international cooperation and coordination. ${ }^{3}$ Scholars have concerned themselves with how countries with overlapping but non-identical interests and preferences can act collectively. With the basic metaphor being the prisoners' dilemma, where the result of each country striving for its most-preferred choice is an outcome that is worse for all actors than had they cooperated and settled mutually on second-best choices, much of the field of IPE has 
been constructed around the problem of collective action and the challenges to achieving international cooperation. Thus, a major strand of IPE scholarship was over the dynamics of "international regimes," the formal and informal arrangements established by countries to establish order and achieve international cooperation. ${ }^{4}$

Scholars of IPE working from varying analytic perspectives offer different solutions to the problem of cooperation. Structuralists (also called "realists") emphasize the role of dominant countries to either supply public goods and essentially permit others to free-ride on their efforts or to impose order by punishing free-riders. ${ }^{5}$ Institutionalists (also called "liberals") emphasize the cooperation-enhancing effect of information provided by procedures and rules and context. ${ }^{6}$ Constructivists focus on the importance of ideas, the emergence of norms, and the role of experts in generating common causal visions of the world. ${ }^{7}$ In this chapter I extend the first of these two perspectives, structuralism and institutionalism, to the topic of international cooperation in "NorthSouth” economic relations.

In applying regime analysis to North-South relations, the first thing to emphasize is that the metaphor of the prisoners' dilemma - and the underlying assumption of common interests - may not be appropriate for the task at hand. With many of the issues of salience in a North-South context, actors' interests and the larger context of strategic interaction are different from in the traditional IPE approaches noted above. Different types of economic issues have different political characteristics, and the "deep integration” issues introduced in the UR have different implications for economic development and thus inter-state politics than standard issues of trade. ${ }^{8}$ The sorts of rules on IP and investment, for example, that developed countries promote on behalf of their firms are unlikely to be embraced by developing countries, and the sorts of policy approaches that many developing countries would prefer are likely to be resisted by their counterparts in the "north.” In the subsequent sections I shall explain the underlying cleavages on IP and investment; for now the key point is simply that the distributional conflicts in these issue-areas are more accentuated and intense than in standard IPE. Indeed, the political challenges are not so much how to achieve collective action but how to reconcile conflicting and often incompatible interests. As many scholars have noted, placing too much attention on how countries achieve international cooperation risks masking the distributive implications of cooperative outcomes. ${ }^{9}$ The substantive issueareas analyzed in this chapter call for a focus on the more starkly distributive dimensions of international cooperation.

Structuralists and institutionalists bring different tools and emphases to bear in analyzing conflict resolution. The former focus on the distribution of resources as the determinant of countries' strategies and the underlying power differentials among countries, while the latter focus on the constraining effects that rules and context have on countries' strategies and forms of behaviour. Actors have conflicting interests, and those with the most "power" prevail, of course - but what determines which actors have more or less “power?” To answer that question, structuralists look the material resources that actors have at their disposal, and institutionalists emphasize rules and procedures. 
When applied to conflict between developed and developing countries, the expectations derived from a structuralist approach are rather simple and straightforward. If rich and poor countries have conflicting interests, to the extent that rich countries have more resources (which by definition they do) and thus power, we should expect rich countries' interests to prevail. Thus structuralists expect the international political economy to reflect the interests of the more developed countries ${ }^{10}$

While the distribution of resources may be a useful predictor of how conflicts will be resolved, it is not without its shortcomings. Actors with more resources obviously do not always impose their will; actors often consent to institutional arrangements (i.e. rules) that mitigate resource differentials and produce outcomes that would be reflective of alternative distributions of power. The question, then, is why actors with more resources would accept institutions that constrain the exercise of their own resources? After all, from a structuralist perspective, such rules distort the "natural" order of things.

Institutionalists provide an answer to this question by concerning themselves with the reasons why actors want rules in the first place. Actors demand institutions because of the invaluable functions that they perform: institutions reduce transaction costs involved in securing information, monitoring activities, and enforcing compliance. Furthermore, by providing standards of behavior that demarcate likely patterns of conduct, institutions increase predictability and reduce uncertainty. ${ }^{11}$ Actors cannot know what the precise outcome of any given interaction will be, but the array and probability of different scenarios can be anticipated, and this certainty and predictability are cherished.

Integrating these simple observations derived from the structuralist and institutionalist approaches leads to the following implications regarding North-South politics in the international economy. First, and most fundamentally, developed countries write the rules. To paraphrase Krasner, there are "makers, breakers, and takers" 12 of international institutions: developed countries are makers, developing countries are takers (and, at times, breakers).

Yet notwithstanding their prevailing rule-making capacities, developed countries may create and abide by rules that fail to reflect underlying distributions of power in order to secure compliance on the part of developing countries and thereby reduce the costs of monitoring and enforcement. Indeed, the prevalence of information asymmetries, which raise the costs of monitoring and enforcement, gives developed countries incentives to establish rules that encourage self-enforcement. That is, more powerful actors' demand for international rules may lead them to accept, as a side effect, the distorting effects that rules can have on the "natural" order of things.

Developing countries are likely to accept, and perhaps appear to embrace, even unfavourable agreements because of the stability and predictability that institutions promise to deliver. For developing countries, the principal advantages of - and thus source of demand for - institutions are the provision of predictability and reduction of uncertainty. The stability that comes from knowing what is and what is not acceptable behaviour can help ameliorate some of the vulnerability that marks developing countries' 
position in the international system. Subjecting interaction to institutions gives actors greater confidence that conflicts will be resolved, if not entirely to their liking at least according to known and recognized procedures.

Stability and predictability come at a high price, however. To secure developed countries' formal commitment to mutually-recognized rules, and thus the bounding of the uncertainty that is endemic to weakness, developing countries must accept and adapt to rules and regulations that are generally not of their making. The upshot, then, is that developing countries may demand and seek to strengthen institutions, even institutions with unfavourable distributional effects, to secure stability and predictability. The key point here is that for weak actors, bad rules that are universally acknowledged are better than no rules, for under conditions marked by power asymmetries no rules are bad rules - they are simply less predictable, changing with the whims of the more powerful actors, and they do not promise reciprocal constraints. This is not to imply that weak actors do not or should not push for "better" rules, only to make sense of why they may work to strengthen international arrangements informed by "bad" rules.

The fact that developed and developing countries all share a demand for institutions, and that the former will tolerate rules that fail to reflect the regnant distribution of resources as the price of securing compliance, provides developing countries with possibilities for being exerting unexpected degrees of influence on regime outcomes, even in issue-areas marked by conflict. That is, developing countries may exploit the opportunities created by institutions and achieve more favourable outcomes than they might otherwise be able to secure. However, such a strategy may have decreasing returns if it destabilizes the institutions by diminishing developed countries' respect of and support for such institutions. ${ }^{13}$

In the remainder of this chapter I use these insights to shed light on North-South conflicts in the WTO over IP and investment.

\section{Politics of Intellectual Property}

The management of IP is a critical component of development policy. National strategies for IP influence trajectories of industrial development and capacities to address humanitarian concerns. As pillars of national systems of innovation, IP regimes drive technological change; they affect trajectories of knowledge-creation and knowledgediffusion. And by affecting access to technologically-intensive goods, such as pharmaceuticals, IP regimes contribute to national public health programs.

To understand the fundamental differences in approach toward managing IP, and hence the underlying conflict in the WTO, a quick review of the issue-area is in order. When governments create intellectual property rights (IPRs), they are granting actors rights of exclusion over knowledge and information. National policy responds to two objectives: encouraging the creation and commercialization of knowledge, and encouraging the dissemination and use of knowledge. Granting and protecting IPRs can 
accomplish the first objective by providing actors with the means - legally enforceable rights of exclusion - to appropriate the returns to their investments in innovation and knowledge production. The catch, however, is that the instrument to achieve the first objective can undermine fulfillment of the second objective, because IPRs - by their very nature - restrict use by converting knowledge into privately owned property where owners set the conditions over use. ${ }^{14}$ In sum, IP regimes have two desirable - but unavoidably conflicting - objectives, that knowledge be generated and that knowledge be used.

Structural characteristics that distinguish developed and developing countries generate different perspectives on how to prioritize the quests for generating and using knowledge, thus leading to conflict over international IP rules. Wealthier countries, with higher levels of innovative capacity and where more research and development tends to produce new knowledge, have tended to opt for setting incentives to encourage and reward knowledge generation. Poorer countries, in contrast, with lower innovative capacities and where most new knowledge is that which is imported from abroad, have tended to opt for setting incentives to encourage dissemination and use of new knowledge. Thus, wealthier countries have historically offered stronger IPRs than poorer countries.

Prior to the 1980s, the international rules on IP permitted the sort of diversity described in the previous paragraph. In the 1980s and 1990s, however, the developed countries, pushed for a less flexible set of international regulations regarding national IP policies. Importantly, these more stringent regulations would be embedded in the international trade system, thus making developing countries' ability to export goods to developed countries' markets conditional on their treatment of IP. ${ }^{15}$

The hallmark of the effort to link higher standards of IP to trade was the inclusion of the TRIPS agreement in the Uruguay Round. Many middle-income developing countries were opposed to the integration of IPRs into the GATT and attempted to block negotiations on IP. Yet IP was a high priority for the developed countries (especially the US and European Community) in the Uruguay Round, and developing countries were unable to keep IP off the negotiating agenda.

In the course of negotiating the TRIPS Agreement, developing countries were able to exploit differences between the US, Europe, and Japan, and thereby prevent inclusion of some of the strictest and most egregious restrictions on national policy, but few could disagree with the conclusion that the developed countries prevailed in getting most of what they wanted out of the negotiations. ${ }^{16}$ TRIPS dramatically alters the international environment for IP policy, precluding - or at least complicating - the use of many instruments that have historically been used to manage knowledge and technology. With regard to patents, for example, the agreement requires countries to grant patents in areas that many countries previously treated as ineligible for patent protection (e.g. pharmaceuticals and chemicals) and places new restrictions on states' ability to issue compulsory licenses. 
In the period since the conclusion of the Uruguay Round and the establishment of the WTO, the North-South conflict over IP has been most intense as regards access to essential medicines. ${ }^{17}$ The reason for this is that there remained substantial uncertainty regarding just what measures countries were and were not allowed to take with regard to compulsory licenses and parallel imports, legal uncertainty that was exacerbated and compounded by developing countries facing considerable political pressure to exceed their new obligations in the area of IP. The principal source of pressure came from the US, which demanded accelerated implementation of TRIPS obligations (i.e. forego transition periods allowed by TRIPS) and discouraged countries from utilizing policy prerogatives (i.e. forego policy measures allowed by TRIPS). The “TRIPS Plus" campaign is illustrated by considering the treatment of developing countries in the USTR's annual Special 301 Reports on IPRs. Throughout the 1990s, developing countries were routinely placed on the Watch List and Priority Watch List for what the U.S. regarded as "insufficient" protection of intellectual property. In the seven years after the WTO entered into effect, more than half of the countries subject to this pressure were developing countries. Developing countries also accounted for nearly two-thirds of the countries identified on the Priority Watch List. Developing countries often found themselves under threat even when they were behaving in compliance with the Uruguay Round's IPR obligations. In pursuit of higher standards of intellectual property protection, the USTR singled out countries that were in compliance with TRIPS but that, in taking advantage of the agreement's flexibilities, had introduced IPR regimes that the U.S. deemed objectionable. Thus, developing countries often found themselves subject to penalties not for violating TRIPS or even for being too slow in making their IPR regimes TRIPS-compliant, but rather for using the flexibility that TRIPS formally permits - for not adapting “TRIPS Plus” regimes.

The focal point of the North-South conflict over IP was over compulsory licenses for essential drugs. A compulsory license allows a public or private actor to use patented knowledge without the authorization of the owner. ${ }^{18}$ Although TRIPS places conditions on countries' ability to issue compulsory licenses, conditions that, as indicated above, are more restrictive than pre-Uruguay Round rules, the agreement does not prohibit the use of CLs. But external pressures certainly discouraged developing countries from taking TRIPS-acceptable measures. Many of the countries included on the USTR's Special 301 lists, for example, were there because of the provisions in their IPR legislation regarding compulsory licenses. And because the US and the major pharmaceutical companies expressed disapproval of the use of flexibilities, countries that took advantage of their rights under TRIPS feared retaliation. ${ }^{19}$ Ultimately, this strong opposition to the use of CLs, and prominent statements regarding their alleged illegality, cast a shadow of doubt and uncertainty over an issue that is already marked by high levels of legal complexity. Indeed, as one developing country representative noted, the challenges presented by CLs' legal complexity was greatly exacerbated by external pressures and the uncertainty as to what falls outside of TRIPS. ${ }^{20}$

Vulnerability to external pressures prompted developing countries to seek real, and not just formal, flexibilities in IP policy. Developing countries, thus, launched a campaign to secure political space to take advantage of their rights under the 
agreement. $^{21}$ The campaign came to the fore in 2001, with a joint WHO/WTO conference on affordable medicines, two Special Sessions of the TRIPS Council dedicated to the same topic, and the WTO's Fourth Ministerial Meeting in Doha. A coalition of more than fifty developing countries sought to use the Ministerial meeting to affirm their rights under TRIPS - to gain assurances that they could use the TRIPS flexibilities for public health purposes without having to worry about reprisals. To that end, they demanded a Ministerial Statement that would eliminate any outstanding ambiguities and uncertainties in TRIPS, and thus shield countries from external pressures that challenged their use of TRIPS-acceptable flexibilities to secure access to essential medicines. ${ }^{22}$

The ensuing statement took the form of the "Doha Declaration on the TRIPS Agreement and Public Health.”23 The Doha Declaration was brief, a seven-section statement, less than two pages long, that was designed to clarify members' obligations and rights under TRIPS. The fourth section, which noted that TRIPS "does not and should not prevent members from taking measures to protect public health," includes as a separate paragraph the critical affirmation of developing countries' rights "to use, to the full, the provisions in the TRIPS Agreement, which provide flexibility for this purpose." The declaration also clarifies countries' rights under Article 31 to issue compulsory licenses: "Each member has the right to grant compulsory licenses and the freedom to determine the grounds upon which such licenses are granted."

The Doha Declaration marks the culmination of a successful campaign to strengthen the multilateral system, in that it can protect developing countries from opportunistic behaviour of developed countries that pressure for TRIPS Plus. ${ }^{24}$ To be sure, the Doha Declaration cannot directly constrain the USTR: - nothing agreed at the WTO could guarantee that the US will not continue to subject countries unilaterally to its own TRIPS Plus standards. Yet the Doha Declaration potentially raises the associated political costs of this sort of opportunistic behavior, for it makes it clear that when the U.S. (or other developed countries) act in this way, they, and not the developing countries, are violating the WTO's rules. ${ }^{25}$ It makes it more obvious that when the US pursues an aggressive TRIPS Plus agenda within the WTO, it is undermining and violating its own multilateral commitments. And while such violations may not be effectively punishable at the global level, they may impose reputation costs on violators. In addition, the agreement provides leverage for domestic political actors who attempt to hold government officials to their multilateral obligations. ${ }^{26}$

This analysis speaks to some of the key issues of this chapter regarding resources and rules in the international political economy. Developing countries' ability to push through the Doha Declaration is rooted in the WTO's consensus rule, which allowed them to make the clarifying Ministerial statement a condition for the formal launching of a new round of multilateral trade negotiations. Developing countries blocked the launching of a new round of multilateral trade negotiations in 1999 at the WTO's Third Ministerial in Seattle, and this history could have been repeated two years later in Doha. Consensus meant that developed countries could not proceed with a new trade round without the consent of the developing countries, and developing countries would not provide this consent without the Doha Declaration on TRIPS and Public Health. 
Although the rules of the WTO clearly empowered developing countries in this regard, allowing them to secure the clarifying statement on the important issue of TRIPS and health, one must be careful not to overstate the degree of empowerment. After all, what, ultimately, developing countries accomplished was clarification and affirmation of a set of already-existing rules that they only grudgingly accepted in the Uruguay Round. It might very reasonably be suggested that genuine empowerment would allow actors to secure new rules that are more in line with their preferences. Indeed, many developing countries may wish to substantially revise - or even abolish - TRIPS, but doing so is clearly beyond their means.

The limits to developing countries’ power and influence are illustrated by looking, briefly, at the aftermath of the Doha Declaration. TRIPS permits countries to issue compulsory licenses, a right reaffirmed by the Doha Declaration, but the remaining uncertainty regarded the export of drugs produced under CL. After all, few countries can produce their own pharmaceuticals, so a compulsory license, to be useful, must permit that drugs can be exported from the countries that do have such manufacturing capacity. Here TRIPS did indeed complicate matters, by requiring that compulsory licenses must be "predominantly" for domestic use (Article 31.f). The Doha Declaration recognized this unresolved business and committed members to finding a solution, and for more than four years addressing this issue consumed the TRIPS Council. Space limitations preclude detailed discussion of these negotiations, ${ }^{27}$ though what is clear is that developing countries were much less successful here and, ultimately, had to settle for what many observers regard as an unsatisfactory resolution. The reason why is that, in contrast to the issues addressed in 2000-2001, which entailed clarifying TRIPS, to resolve the CL-forexport issue to their liking developing countries would have had to secure substantive reforms of TRIPS. ${ }^{28}$

\section{Politics of Investment}

Managing inward DFI has historically been a key point of economic development policy. States regulate international investors, quite simply, because what is best for individual enterprises may not be best for all of society. Even states that are largely neoliberal in orientation, i.e. guided by the principle that private actors' autonomous decisions regarding resource allocation are optimal, are likely to regulate international firms, because local subsidiaries of transnational firms do not make resource allocation decisions "autonomously" but rather in coordination with (if not under control of) their parent firms.

As in the case of IP, the "North-South" conflict over international investment regulation (IIR) is rooted in economic structure. Most DFI (roughly eighty percent) occurs among advanced, industrial economies. Developed countries, thus, approach the area of IIR as capital exporters and capital importers: Canada and France regulate foreign investors, for example, and Canadian and French firms are subject to regulations in other countries. Developing countries, in contrast, approach the area of IIR as capital importers: Argentina and Senegal regulate foreign investors but few Argentinean and 
Senegalese firms are subject to other countries’ regulations. ${ }^{29}$ Furthermore, developed and developing countries' interests as capital importers are not the same either, because of the different roles that DFI tends to play in the local economy. Foreign investors tend to be concentrated in different sectors, use different modes of entry, and account for different shares of investment, production, exports, and so on.

Thus, similar to what we see in the case of IP, structural characteristics lead to differing perspectives on investment and, subsequently, persistent conflict in the area of IIR. Developed countries seek limited regulations on investors, while developing countries have historically sought the right to use policy instruments designed to harness the benefits of DFI. These instruments include, for example, local content requirements, screening entry of foreign investors, equity limitations (i.e. making joint ventures compulsory), controls on repatriation of profits and export of capital, and requirements regarding technology transfer and the training of human resources.

Although there is little new about the basic observation that states seek to regulate inward investment and the claim that conflicts over IIR are rooted in structural differences between countries, a set of changes that have occurred since the 1980s have brought increased prominence to the issue-area. From the perspective of developing countries (i.e. capital importers), we see a new orientation in the wake of debt and protracted economic crises in the 1980s and 1990s and, subsequently, widespread trade liberalization and privatization. Attracting DFI has become, in most if not all developing countries, one of the primary objectives of economic policy. Countries seek investors as exporters (and, hopefully, purveyors of skills and technologies); countries seek foreign investors as purchasers of privatized state enterprises and suppliers of public services (particularly when, as is often the case in poorer countries, local private actors lack the capital to take over the state's role). Most generally, whereas in the past many governments were wary of DFI and preferred the autonomy that came from borrowing from international banks, ${ }^{30}$ in the current environment foreign investors have come to be regarded - and desired - as more stable and less mobile forms of capital inflow. Thus, as countries become more desiring of and dependent on DFI, they are more wary of frightening away potential investors with “over-regulation,” and this changes their approach to the area of IIR.

We also see a change from the perspective of developed countries (i.e. capital exporters), in that the nature of DFI in developing countries has undergone a shift since the 1980s. Whereas DFI had historically been in extractive industries or tariff-hopping manufacturing sectors, the contemporary environment is marked by the proliferation of “efficiency-seeking” foreign investors seeking to use developing countries as export platforms, and by “market-seeking” foreign investors taking over formerly state-reserved roles of public service and infrastructure provision. Linked to this change, especially the growth of DFI in public services, are new concerns on the part of investors as they move into sectors that are, by their very nature, more heavily regulated and more vulnerable to expropriation. Also worth noting here is that as international operations represent increased shares of some global firms' revenues, the subject of how subsidiaries are regulated becomes more important. 
The upshot of these two sets of changes is that the issue of international investment, always a hot topic in "North-South" international political economy, has gained increased importance. Capital importing countries have become more desiring of and dependent on DFI (and thus wary of potentially frightening investors with "overregulation"), and the interest of capital exporting countries has grown on account of the greater number and variety of firms with a stake in the rules of IIR.

Now let's turn to analysis of the North-South politics of IIR in the GATT and WTO. As in the case of IP, investment was a domain where countries historically retained a great deal of policy autonomy; and as in the case of IP, the 1980s would witness an effort by developed countries to embed a more restrictive set of rules on investment regulations in the international trade regime. Here too the Uruguay Round provided the setting, as developed countries (again, the US as lead demandeur) pushed for an agreement that would restrict countries' abilities to impose investment regulations on foreign firms. ${ }^{31}$

The history of the TRIMS Agreement shares many features with the history of the TRIPS Agreement, in that developing countries first resisted inclusion of any negotiations at all (arguing that investment was not "trade-related"), and second, when unsuccessful in keeping the issue off the Uruguay Round agenda, strongly resisted the content of an agreement that threatened to impinge negatively on their autonomous economic policy prerogatives. ${ }^{32}$ Where the two histories differ, however, is that in the area of investment, developing countries were much more successful at exploiting differences among developed countries and diluting the final agreement. To understand this, it is important to appreciate the breadth of the investment agreement that the US initially sought in the UR: the US negotiating objectives extended significantly beyond local content requirements per se, and included binding regulations on a wide array of investment policies. Indeed, the US sought to restrict specific policies, regardless of their demonstrated effects on trade. Not surprisingly, developing countries actively resisted such a broad agreement, and the Uruguay Round's investment negotiations were marked by deadlock. Eventually a compromise was reached to limit the agreement to policies with direct effects on trade. ${ }^{33}$

The subsequent Agreement on Trade-Related Investment Measures (TRIMS) is a fairly narrow agreement in that it addresses, as the name suggests, "trade-related" investment measures, while leaving countries with significant degrees of latitude regarding investment regulation more generally. After all, the agreement does not offer a precise definition of what a "trade-related investment measure" is, nor does it establish criteria for identifying such measures. The agreement simply provides examples of prohibited regulations in the form of an "illustrative list" in the appendix, which countries are expected to identify and eliminate. Beyond the measures explicitly included in the appendix, however, TRIMS lets countries determine what is and what is not a "traderelated investment measure," and, critically, which of their investment measures need to be retired. Investment measures that do not violate national treatment or impose quantitative restrictions on firms' imports and exports are legal. Thus, states can screen 
entry of foreign firms, for example, and demand joint ventures or require foreign firms to transfer technology to local firms. And states can regulate foreign investors' hiring practices, with the aim of enhancing development of human capital and skills. Even under the more restrictive international regime on investment, developing countries can continue to use standard and time-honoured investment regulations as instruments of industrial promotion.

To be sure, the agreement does outlaw key investment regulations that have been at the heart of many countries' development strategies, most importantly local content requirements, which demand investors to source their inputs locally, and also trade and balancing requirements, which oblige foreign investors to include sufficiently high levels of domestic inputs in exports to offset imported inputs. Both of these regulations aim to generate backwards linkages from foreign investors to local manufacturers, and outlawing them clearly takes away developing countries' ability to use important policy instruments to increase local value-added, employment, and industrial upgrading. Yet while it would be unwise and inappropriate to downplay the significance of these particular - and now prohibited - policy instruments, one cannot but help but note that TRIMS is significantly less restrictive than its advocates originally sought (and certainly less restrictive and intrusive than TRIPS). In fact, some of these prohibitions enshrined in TRIMS actually predate the Uruguay Round. For example, it was under the GATT that local content rules were deemed illegal. ${ }^{34}$

Developed countries' dissatisfaction with the outcome achieved in the TRIMS negotiations could be seen in the immediate aftermath of the conclusion of the Uruguay Round. No sooner was the new WTO established, and developed countries sought to reinitiate negotiations in pursuit of a more broad-based international investment agreement. Developed countries (now the EU more than US) made investment a high priority at the WTO’s Second Ministerial Meeting in Singapore in 1996. Once again, however, developing countries opposed this effort, and the North-South cleavage on investment that marked the Uruguay Round remained evident in the post-Uruguay Round setting. Developed countries sought a broad-based agreement, more akin to the investment chapter in the North American Free Trade Agreement and the many bilateral investment treaties (BITs) that were proliferating in the 1990s, which proscribe a wide range of investment measures; developing countries, seeking to hold the line at TRIMS, attempted to keep investment off the negotiating agenda. The compromise settlement was to create a WTO Working Group on Trade and Investment, which would continue to study the issue. $^{35}$

Before proceeding to discussion of the deadlock's resolution (or not), it is worth underscoring some of the underlying factors that contributed to the North-South stalemate over investment. Most obviously and most directly, this was a disagreement over the policy flexibility and developing countries' rights and capacities to regulate inward DFI. The TRIMS agreement may have been inadequate from the perspective of capital-exporting countries, but few capital importers were likely to agree to a project that would make binding regulations more restrictive. Moreover, even developing countries that may have had few reservations regarding the substantive dimensions of such an 
agreement, i.e. governments that are "neoliberal” in orientation and unilaterally removing the sorts of provisions that would be prohibited by such an agreement, had ample reasons to oppose the inclusion of a broad-based investment provision in the WTO. Many countries complained of negotiation and implementation "overload" and, critically, asymmetric risks of exposure to dispute settlement. Beginning negotiations on investment means yet another issue where countries need to find the resources to participate, and any subsequent agreement would lead to yet one more WTO standing body where countries would need to be represented. Moreover, since the subsequent rules would be binding on governments in capital-importing countries, what developing countries would be consenting to would be a legal framework in which they would find themselves more likely than not in the position of defendant. ${ }^{36}$

When the Doha Round was formally launched in November 2001, investment was included on the agenda (paragraphs 20-22 of the Ministerial Declaration). The declaration recognized countries' fundamental right to regulate investors and declared that were any negotiations to occur they would proceed on the basis of a "positive list" (like the GATS), meaning that countries put forward the sectors where they are prepared to negotiate. Yet, notwithstanding these substantive concessions, developing countries (for reasons alluded to in the previous paragraph) were not prepared to negotiate. Indeed, as a result of the strong resistance of a coalition of developing countries led by India and Malaysia (the "Like-Minded Group”), the Ministerial Declaration also stipulated that negotiations on investment would proceed only on the basis of "explicit consensus." That is, in contrast to ordinary WTO rules of implicit consensus, which requires a country to actively dissent to block consensus (and thus encourages negotiations in closed "green room” sessions), the explicit consensus rule for investment required all WTO members to actively consent to taking negotiations forward.

By the time of the WTO’s Fifth Ministerial Meeting in Cancún in 2003, the WGTI had received nearly fifty submissions, ${ }^{37}$ but the precise mandate of Ministers remained unclear. Many developed countries (especially the EU) interpreted the Doha Ministerial Declaration such that the requirement was for explicit consensus on the "modalities" (i.e. the basic terms of agreement). To that end, the Canadian facilitator for negotiations on investment (and all the "Singapore Issues"), attempted to push forward, on the basis of the submissions received by the WGTI, and reach agreement on modalities. Developing countries resisted both this interpretation of the Doha Ministerial Declaration and the efforts of the Canadian chair, insisting that without explicit consensus negotiations could not even proceed. Indeed, a coalition of sixty developing countries formally opposed negotiations in the absence of the "explicit consensus," and, ultimately, refused to negotiate. This refusal, which is what Smythe refers to as "just saying no," contributed to the end of the Cancún Ministerial and meant that investment was effectively removed from the Doha Round agenda. ${ }^{38}$ While, at the time of writing (July 2008), the future of the Doha round as a whole is uncertain, whatever comes out of the negotiations will almost certainly not include investment. TRIMS, for better or worse, is and will remain the WTO status quo for the foreseeable future. 
The ability of developing countries to block investment negotiations was a function of the WTO's rules. The Doha Round would not begin if any country objected (negative consensus rule), so India could condition its authorization of the 2001 Ministerial Declaration on the inclusion of what amounted to a "poison pill" in the area of IIR. This is a clear instance of institutions providing actors with power and influence that are disproportionate to their underlying resources.

Yet, as "victories” go, this is a rather limited outcome. From a development perspective, TRIMS only looks good when contrasted to what the developed countries sought in the Uruguay Round, sought in the MAI, included in many bilateral investment treaties (and investment chapters of RBTAs), and in proposals made to the WGTI. ${ }^{39}$ Developing countries have been able to ward off "more unfavourable" outcomes, but they have not been able to secure outcomes in line with their preferences. They could not revise the TRIMS Agreement, as many sought, by placing binding obligations on investors and home countries and restoring the right to use some investment measures that were prohibited during the Uruguay Round. In short, they could prevent a "bad situation” (TRIMS) from getting worse, so to speak, but they remain unable to fashion an outcome that matches - or even approximates - their preferences. Developing countries lack the power to accomplish that goal.

\section{Conclusion}

In reviewing the North-South politics of IP and investment, I have shown how institutional arrangements - in particular the consensus rules of the WTO - can give weaker actors more power and influence than we might expect from simply reading off the underlying distribution of resources. After all, developed countries are stronger and, subsequently, a structuralist approach would lead us to expect them to be able to impose their preferences. Yet they have not: for all their efforts to rewrite the rules regarding IP and investment in the post-Uruguay Round period, they have not succeeded. Developing countries - weak as they may be - have seen to it that the WTO's rules on IP and investment are essentially the same in 2008 as they were at the conclusion of the Uruguay Round in 1994. This finding represents a clear tick in the institutionalists' column.

Yet all the power developing countries have exercised has been essentially “blocking” power. In both instances, developing countries would like to introduce more substantive reforms, both to TRIPS and TRIMS, but have been unable to do so. Instead they settle for clarification of rules that most countries strongly objected to in the first place and preventing the imposition of what many regard as even more unfavourable rules. Developing countries have been able to prevent (or at least limit) the imposition of rules that exceeded what they agreed to in the Uruguay Round, either by clarifying the rules and thus creating a check on unilateral pressures (IP) or preventing additional multilateral negotiations (investment). What they have been unable to do, however, is act proactively - to secure agreement on new WTO rules that are more to their liking. ${ }^{40}$ 
Of course, the ability of developing countries to block developed countries' initiatives in the areas of IP and investment only begs the more critical question of why, if they can do this now, they could not do it before and stop these agreements in the first place. Or to put it differently, if developing countries can prevent the unfavourable Uruguay Round agreements from being supplanted by a set of more unfavourable Doha Round agreements, why could they not prevent the more favourable Tokyo Round agreements from being supplanted by the unfavourable Uruguay Round agreements? After all, they did try: as discussed, developing countries opposed TRIPS and TRIMS in the Uruguay Round, just as they oppose developed countries' TRIPS-Plus and TRIMSPlus initiatives in the contemporary environment. Why did they acquiesce to the former but block the latter? The answer to this question gets to the heart of the analysis, and in particular the interface between institutionalist and structuralist approaches. Addressing this question, then, sheds light on both the importance and limitations of international institutions.

The existence of a "single undertaking" is frequently invoked as an explanation for why developing countries accepted TRIMS and TRIPS in the Uruguay Round. In previous rounds, countries chose whether or not to sign on to supplemental codes, but the single undertaking meant that the Uruguay Round was an all or nothing affair. But that explanation is unsatisfactory without considering the exercise of power that made the introduction of this institutional device feasible and, moreover, effective. After all, the single undertaking itself was new - an institutional reform introduced to gain developing countries' consent to agreements that they had resisted. ${ }^{41}$

The key to making the single undertaking work was to make the WTO the only game in town. That is, the way to get developing countries to accept a set of Uruguay Round agreements that they had fiercely rejected was to make the alternative to acceptance being excluded from the international trade regime. But how to do that? After all, many developing countries were already members of the GATT, which offered MFN access to the developed countries' markets. Any tariff reductions made in the Uruguay Round, then, would have to be granted on a MFN basis to GATT members, even if they rejected TRIPS and TRIMS. Thus the key would be to eliminate the GATT from the shadows of the WTO.

At the end of the Uruguay Round, all countries who participated in the negotiations signed the "Final Act" and thus became signatories to all the various WTO agreements. One of the texts included in the Final Act was the GATT 1994, a new agreement that incorporated - but superseded - the GATT 1947. The Uruguay Round's Final Act stipulates that GATT 1994 is "legally distinct" from GATT 1947. Most importantly - and this is the frequently overlooked point - immediately upon joining the WTO (including GATT 1994) the US and EC both withdrew from GATT 1947, thus terminating their obligations under GATT $1947 .{ }^{42}$ Any country that did not sign Uruguay Round's Final Agreement and join the WTO would, formally, retain their rights under GATT 1947, but since the largest countries with the most important markets were no longer bound by GATT 1947, non-joiners would be left with empty rights. The result of 
this is that MFN-based market access is only available to countries that joined the WTO, thereby consenting TRIPS and TRIMS and GATS and the ASCM and so on.

This review of how developed countries exercised power to create an institutional device (the single undertaking) that would secure a favourable outcome of the Uruguay Round remains relevant for the subsequent analysis of the Doha Round that I have discussed in this chapter. The case of IP and investment negotiations in the Doha Round shows how unweighted voting and the consensus system give developing countries unexpected power. The WTO's decision making procedures inflate developing countries' power; institutions are endowing countries with influence that they would otherwise lack in the absence of these rules. Developing countries could condition the launch of a new round of multilateral trade negotiations, which developed countries had sought since 1996, on an agreement that would draw the line under TRIPS Plus demands, and they could make sure that the subsequent round did not include negotiations on investment.

The key point, however, is that we see this power-enhancing effect because the WTO already exists, and, in contrast to the early 1990s, no one is (yet - but see below) talking about effectively replacing the WTO with a new international trade institution. In other words, the "power play" described by Steinberg is not being replicated. ${ }^{43}$ In the Uruguay Round, developing countries were weakened because a new organization was created that supplanted the existing organization, which meant that the consequences of blocking conclusion would have been to be left out in the cold, not in the new WTO and members of an old - and now useless - GATT 1947. In the current environment, however, the consequences of blocking conclusion of Doha Round is maintenance of the status quo. Developing countries' power, albeit only “blocking power," is derived from the fact that they are in WTO and cannot be excluded or expelled from the WTO.

This discussion speaks to Gruber's insights that some countries might sign agreements that they do not like because the alternative is not the status quo but something worse than the status quo - and that more powerful countries with resources to "go it alone" can present weaker countries with this new choice set. ${ }^{44}$ Such dynamics help explain the conclusion of the Uruguay Round, and their absence helps explain the persistent deadlock in the Doha Round. Developing countries have less to fear in the current setting because developed countries are no longer exercising what Gruber refers to as their "go it alone power." As a result, obstinate resisters are not left facing something worse than the status quo.

To conclude, it is worth questioning the sustainability of the scenario. Developing countries' newfound influence in international trade negotiations is derived from the institutional setting, but for that very reason the power is extremely fragile. Institutions that generate outcomes that deviate far from what might be expected from the underlying distribution of resources are unstable. ${ }^{45}$ Developed countries closed one institution and created another in the 1990s. Would they do that again? Legally they can: withdrawing from GATT 1994 is as simple as withdrawing from GATT 1947 was. Yet there is little evidence of any schemes to replace the existing international trading regime with a new one. Perhaps the proliferation of regional agreements is a movement in that direction, a 
de facto (if not explicit) effort to leave the WTO and create a new WTO-plus world that those developing countries on the outside will feel compelled to join - just as developed countries left GATT 1947 and created a new GATT-plus world that resisters to the Uruguay Round found compelled to join. There are sound reasons to question the viability of regional and bilateral strategy, but just raising it as a possibility speaks to the fragility of rule-based power and the undying importance of the distribution of resources in the shaping of the international economic order.

Kenneth C. Shadlen is a Senior Research Fellow with GDAE's Globalization \& Sustainable Development Program and a senior lecturer of Development Studies at the London School of Economics and Political Science. Inquiries can be directed to k.shadlen@lse.ac.uk 


\title{
Endnotes
}

\begin{abstract}
${ }^{1}$ I use the quotation marks to qualify the verb. As we shall see, in both instances developing countries blocked outcomes that they regarded as worse than the status quo, so they "prevailed" by securing the better (less worse) of two outcomes. Yet most developing countries also oppose the status quo, and they have not been able to replace it by achieving agreements on international rules that are more aligned to their preferences. Hence the need to qualify the word “prevail.” I address these issues throughout the chapter.

${ }^{2}$ See, for example, Jock A. Finlayson and Mark W. Zacher, "International Trade Institutions and the North-South Dialogue,” International Journal 36 (Autumn 1981): 732-765; Stephen D. Krasner, Structural Conflict: The Third World Against Global Liberalism (Berkeley and Los Angeles: University of California Press, 1985); David A. Lake, "Power and the Third World: Toward a Realist Political Economy of NorthSouth Relations,” International Studies Quarterly 31 (June 1987): 217-234; John Gerard Ruggie, "Political Structure and Change in the International Economic Order: The North-South Dimension,” in J.G. Ruggie, ed., The Antinomies of Interdependence: National Welfare and the International Division of Labor (New York: Columbia University Press, 1983): 423-487; Kenneth C. Shadlen, "Patents and Pills, Power and Procedure: The North-South Politics of Public Health in the WTO,” Studies in Comparative International Development 39 (Autumn 204): 76-108. Diana Tussie, The Less Developed Countries and the World Trading System: A Challenge to the GATT (New York: St. Martin's Press, 1987); Robert H. Wade, "The Ringmaster of Doha,” New Left Review. 25 (January-February 2004): 146-152.
\end{abstract}

${ }^{3}$ Stephen D. Krasner, ed., International Regimes (Ithaca: Cornell University Press, 1983); Kenneth A. Oye, ed., Cooperation under Anarchy (Princeton: Princeton University Press, 1986); Arthur A. Stein, Why Nations Cooperate: Circumstance and Choice in International Relations (Ithaca: Cornell University Press, 1993). For a more recent reviews of this body of literature, see Vinod K. Aggarwal and Cédric Dupont, "Collaboration and Co-Ordination in the Global Political Economy,” in John Ravenhill, ed., Global Political Economy, Second Edition (Oxford University Press, 2007); Lloyd Gruber Ruling the World: Power Politics and the Rise of Supranational Institutions (Princeton University Press, 2000); Lisa L. Martin and Beth A. Simmons, "Theories and Empirical Studies of International Institutions," International Organization 52 (Autumn 1998): 729-757.

${ }^{4}$ Krasner, International Regimes. See also, Aggarwal and DuPont, “Collaboration and Co-Ordination”; Beth Simmons and Stephan Haggard, “Theories of International Regimes,” International Organization 41 (Summer 1987): 491-518; Robert Keohane, After Hegemony (Princeton: Princeton University Press, 1984).

${ }^{5}$ Stephen Krasner, “State Power and the Structure of International Trade,” World Politics 28 (April 1976): 317-347; Charles Kindelberger, The World in Depression 1929-1939 (Berkeley: University of California Press, 1973).

${ }^{6}$ Keohane, After Hegemony; Robert Axelrod and Robert Keohane, “Achieving Cooperation Under Anarchy: Strategies and Institutions,” in Oye, Cooperation Under Anarchy; Lisa L. Martin, "The Political Economy of International Cooperation,” in Inge Kaul, Isabelle Grunberg, and Marc A. Stern, ed., Global Public Goods: International Cooperation in the 21st Century (Oxford University Press, 1999), pp. 51-64.

${ }^{7}$ Ernst B. Haas, "Why Collaborate? Issue-linkage and International Regimes,” World Politics 32 (April 1980): 357-405; Ernst B. Haas, When Knowledge is Power: Three Models of Change in International Organizations (Berkeley: University of California Press, 1990). See also the special issue of International Organization 46 (Winter 1992), dedicated to the theme "Knowledge, Power, and International Policy Coordination."

${ }^{8}$ Nancy Birdsall and Robert Z. Lawrence, “Deep Integration and Trade Agreements: Good for Developing Countries?” in Inge Kaul, Isabelle Grunberg, and Marc A. Stern, ed., Global Public Goods: International Cooperation in the $21^{\text {st }}$ Century (Oxford University Press, 1999): 128-151; Stephan Haggard, Developing Nations and the Politics of Global Integration (Washington, D.C. : Brookings Institution, 1995); Kenneth C. Shadlen, "Exchanging Development for Market Access? Deep Integration and Industrial 
Policy under Multilateral and Regional-Bilateral Trade Agreements," Review of International Political Economy 12 (December 2005): 750-775.

${ }^{9}$ Stephen D. Krasner, "Global Communications and National Power: Life on the Pareto Frontier," World Politics 43 (April 1991): 336-66; Martin and Simmons, "Theories and Empirical Studies”; Gruber, Ruling the World.

${ }^{10}$ Examples of such analyses include Krasner, Structural Conflict; Lake, "Power and the Third World"; Susan Strange, "Cave! Hic Dragones: A Critique of Regime Analysis,” in Krasner, ed., International Regimes; Robert Tucker, The Inequality of Nations (New York: Basic Books, 1987). What drives countries' interests, however, is a further question. Some scholars regard interests as a function of actors' position in the international system, while others focus on how domestic policymaking processes shape national interests and goals.

${ }^{11}$ Examples of prominent institutionalist approaches to IPE that emphasize the uncertainty-reducing role of rules include Keohane, After Hegemony; Martin, "The Political Economy of International Cooperation"; Kenneth Abbott and Duncan Snidal, "Why States Act through Formal International Organizations,” Journal of Conflict Resolution 42 (February 1998): 3-32.

${ }^{12}$ Stephen D. Krasner, "US Commercial and Monetary Policy: Unraveling the Paradox of External Strength and Internal Weakness," International Organization 31 (Autumn 1977): 636.

${ }^{13}$ In his analysis of North-South conflict in the 1980s, for example, Krasner showed that where institutional arrangements allowed developing countries to influence that was disproportionate to their resources, developed countries simply stopped participating. See Krasner, Structural Conflict. I return to this point in the conclusion.

${ }^{14}$ To the extent that legal security derived from IPRs encourage owners to share (i.e. license) their knowledge, IPRs may also contribute to knowledge dissemination. Yet where third parties can access knowledge without the help of the owner, the costs imposed on third parties for using knowledge is greater in the presence of IPRs than in their absence.

${ }^{15}$ See, among others, Peter Drahos, "Global Property Rights in Information: The Story of TRIPS at the GATT,” Prometheus 13 (June 1995): 6-19; Duncan Matthews, Globalising Intellectual Property Rights: The TRIPs Agreement (Routledge, 2002); Susan K. Sell, Private Power, Public Law: The Globalization of Intellectual Property Rights (London: Cambridge University Press, 2003); Kenneth C. Shadlen, Andrew Schrank, and Marcus Kurtz, "The Political Economy of Intellectual Property Protection: The Case of Software,” International Studies Quarterly 49 (2003): 45-71.

${ }^{16}$ Matthews, Globalising Intellectual Property Rights; Jayashree Watal, Intellectual Property Rights in the World Trade Organization: The Way Forward for Developing Countries (New Dehli: Oxford University Press [India], 2001).

${ }^{17}$ This discussion draws on Shadlen, "Patents and Pills, Power and Procedure."

${ }^{18}$ Article 31 of TRIPS addresses compulsory licenses.

${ }^{19}$ South Africa is the most prominent case, of course, but a number of countries were punished by the USTR (e.g. loss of GSP benefits) for failing to meet US standards' TRIPS Plus demands.

${ }^{20}$ Comments of Francisco Cannabrava, Brazilian delegate to TRIPS Council, at the meeting of the Commission on Intellectual Property Rights, "How Intellectual Property Rights Could Work Better for Developing Countries and Poor People,” Session 6: Medicines and Vaccines, 22 February 2002.

${ }^{21}$ The June 2001 remarks of Thailand's delegate to the TRIPS Council are illustrative of the campaign's demands and the issues at play. "We are all aware that TRIPS provides built-in flexibilities regarding measures WTO members can take to obtain medicines, both patented and non-patented, from the best and cheapest sources, both foreign and local. However, due to lack of clarity of certain provisions of the Agreement, developing countries seem to be reluctant to take measures that they are entitled to under the Agreement. This is very unfortunate, because one of the purposes of the Agreement was to establish an international benchmark for intellectual property protection and to prevent unilateral pressure, as stated in 
the Preamble [of the TRIPS Agreement]." Special Discussion on Intellectual Property and Access to Medicines, June 2001 (IP/C/M/31).

${ }^{22}$ The formal proposal for a declaration was made by the Africa Group in alliance with Bangladesh, Barbados, Bolivia, Brazil, Cuba, Dominican Republic, Ecuador, Haiti, Honduras, India, Indonesia, Jamaica, Pakistan, Paraguay, Philippines, Peru, Sri Lanka, Thailand, Venezuela (IP/C/W/296). A number of other developing countries articulated similar positions in the WTO Council without formally endorsing the Africa Group's proposal.

${ }^{23}$ WT/MIN(01)/DEC/W/2, 14 November 2001, hereafter referred to as the "Doha Declaration.”

${ }^{24}$ Shadlen, "Patents and Pills, Power and Procedure."

${ }^{25}$ The US makes the adoption of TRIPS Plus policies a condition for signing regional and bilateral trade agreements (RBTAs), for example, but at least in those agreements the US also makes "WTO Plus" concessions in terms of market access (Shadlen, "Exchanging Development for Market Access").

${ }^{26}$ Andrew P. Cortell and James W. Davis, Jr., "How Do International Institutions Matter? The Domestic Impact of International Rules and Norms,” International Studies Quarterly 40 (December 1996): 451-478.

${ }^{27}$ Frederick M. Abbott, "The WTO Medicines Decision: World Pharmaceutical Trade and the Protection of Public Health,” The American Journal of International Law 99 (2005): 317-358; Duncan Matthews, "WTO Decision on Implementation of Paragraph 6 of the Doha Declaration on the TRIPS Agreement and Public Health: A Solution to the Access to Essential Medicines Problem?” Journal of International Economic Law 7 (2004): 73-107; Duncan Matthews, "From the August 30, 2003 WTO Decision to the December 6, 2005 Agreement on an Amendment to TRIPS: Improving Access to Medicines in Developing Countries?” Intellectual Property Quarterly 10 (2006): 91-130.

${ }^{28}$ To buttress the point about developing countries' inability to introduce changes to TRIPS, one could note on-going - and thus far unsuccessful - efforts to make disclosure of origin in patent applications a requirement or to buttress the system of technical assistance.

${ }^{29}$ This is beginning to change, of course, with the rise of TNCs from developing countries, but this phenomenon is fairly new and remains, in the grand picture, marginal.

${ }^{30}$ Jeff Frieden "Third World Indebted Industrialization: International Finance and State Capitalism in Mexico, Brazil, Algeria, and South Korea,” International Organization 35 (Summer 1981): 407-431.

${ }^{31}$ In fact, the earlier in the 1980s, prior to the launch of the Uruguay Round, the US lodged a GATT dispute against Canada over the latter's foreign investment regulations. Specifically, the US claimed that Canada's local content requirements, which demanded that firms source a given percentage of their inputs from local suppliers, constituted a non-tariff measure that illegally restricted trade. The US won the case, and then sought to generalize the ruling with an agreement on investment in the Uruguay Round.

${ }^{32}$ Mohamed Ariff, “TRIMs: A North-South Divide or a Non-Issue?” World Economy 12 (September 1989): 347-360; V.N. Balasubramanyam, "Putting TRIMs to Good Use,” World Development 19 (September 1991): 1215-1224; David Greenaway, “Why are we Negotiating on TRIMs?” in David Greenaway et al., ed., Global Protectionism (Macmillan, 1991): 145-167. United Nations Development Program, Making Global Trade Work for People (London: Earthscan, 2003): chapter 12.

${ }^{33}$ The compromise was based on a proposal made jointly by Colombia and Switzerland, which focused on assessing the direct trade effects of investment measures, and not the measures themselves.

\footnotetext{
${ }^{34}$ The reference here is to the US challenge to local content requirements in Canada's sectoral automotive policy (see above, note 32). It is also worth noting that many developing countries, as part of their autonomous liberalization processes and efforts to attract DFI in new sectors for export, were already removing many regulations on foreign investors. In fact, some countries - independently of the WTO now present investors with completely different sets of incentives in the form of preferential tax treatment on imported inputs. Thus, instead of regulating foreign investors to promote local suppliers, many countries now promote exports at the expense of local suppliers.
} 


\footnotetext{
${ }^{35}$ It was in response to the perceived inadequacy of TRIMS and the failure to launch new investment negotiations at the Singapore Ministerial that many came to regard the OECD as a more appropriate forum, and negotiations soon began in that forum on a "Multilateral Agreement on Investment” (MAI).

${ }^{36}$ Note that in 1997 India (and later, in 2002, a handful of other developing countries) did propose also regulating the behaviour of firms and TNCs' home governments, but these proposals had little traction and were not taken seriously.

${ }^{37}$ Elizabeth Smyth, “Just Say No! The Negotiation of Investment Rules at the WTO,” International Journal of Political Economy 33 (Winter 2003): 70, table 1.

${ }^{38}$ Ibid.

${ }^{39}$ For another analysis of developing countries' blocking power in the area of international investment negotiations, see Eduardo Plastino, "Investments and the WTO,” Msc Dissertation, Development Studies Institute, London School of Economics, 2008. On file with author.

${ }^{40}$ As I have argued elsewhere, bad rules may be better than no rules - but they are still bad rules! See Shadlen, "Patents and Pills, Power and Procedure"; "Intellectual Property, Trade, and Development: Can Foes be Friends?” Global Governance 13 (June 2007): 171-178.

${ }^{41}$ Richard Steinberg, "In the Shadow of Law or Power? Consensus-Based Bargaining and Outcomes in the GATT/WTO,” International Organization 56 (2002): 339-374.

${ }^{42}$ Ibid.

${ }^{43}$ Steinberg, "In the Shadow of Law or Power?”: 360

${ }^{44}$ Gruber, Ruling the World.

${ }^{45}$ Krasner, Structural Conflict.
} 
The Global Development And Environment Institute (GDAE) is a research institute at Tufts University dedicated to promoting a better understanding of how societies can pursue their economic goals in an environmentally and socially sustainable manner. GDAE pursues its mission through original research, policy work, publication projects, curriculum development, conferences, and other activities. The "GDAE Working Papers" series presents substantive work-in-progress by GDAE-affiliated researchers. We welcome your comments, either by e-mail directly to the author or to G-DAE,

Tufts University, 44 Teele Ave., Medford, MA 02155 USA; tel: 617-627-3530; fax: 617-627-2409; e-mail: gdae@tufts.edu; website: http://ase.tufts.edu/gdae.

\section{Papers in this Series:}

00-01 Still Dead After All These Years: Interpreting the Failure of General Equilibrium Theory (Frank Ackerman, November 1999)

00-02 Economics in Context: The Need for a New Textbook (Neva R. Goodwin, Oleg I. Ananyin, Frank Ackerman and Thomas E. Weisskopf, February 1997)

00-03 Trade Liberalization and Pollution Intensive Industries in Developing Countries: A Partial Equilibrium Approach (Kevin Gallagher and Frank Ackerman, January 2000)

00-04 Basic Principles of Sustainable Development (Jonathan M. Harris, June 2000)

00-05 Getting the Prices Wrong: The Limits of Market-Based Environmental Policy (Frank Ackerman and Kevin Gallagher, September 2000)

00-06 Telling Other Stories: Heterodox Critiques of Neoclassical Micro Principles Texts (Steve Cohn, August 2000)

00-07 Trade Liberalization and Industrial Pollution in Mexico: Lessons for the FTAA (Kevin Gallagher, October 2000) (Paper withdrawn- see www.ase.tufts.edu/gdae/ for details)

00-08 Waste in the Inner City: Asset or Assault? (Frank Ackerman and Sumreen Mirza, June 2000)

01-01 Civil Economy and Civilized Economics: Essentials for Sustainable Development (Neva Goodwin, January 2001)

01-02 Mixed Signals: Market Incentives, Recycling and the Price Spike of 1995. (Frank Ackerman and Kevin Gallagher, January 2001)

01-03 Community Control in a Global Economy: Lessons from Mexico’s Economic Integration Process (Tim Wise and Eliza Waters, February 2001)

01-04 Agriculture in a Global Perspective (Jonathan M. Harris, March 2001)

01-05 Better Principles: New Approaches to Teaching Introductory Economics (Neva R. Goodwin and Jonathan M. Harris, March 2001)

01-06 The \$6.1 Million Question (Frank Ackerman and Lisa Heinzerling, April 2002)

01-07 Dirt is in the Eye of the Beholder: The World Bank Air Pollution Intensities for Mexico (Francisco Aguayo, Kevin P. Gallagher, and Ana Citlalic González, July 2001)

01-08 Is NACEC a Model Trade and Environment Institution? Lessons from Mexican Industry (Kevin P. Gallagher, October 2001)

01-09 Macroeconomic Policy and Sustainability (Jonathan M. Harris, July 2001) 
02-01 Economic Analysis in Environmental Reviews of Trade Agreements: Assessing the North American Experience. (Kevin Gallagher, Frank Ackerman, Luke Ney, April 2002)

03-01 Read My Lips: More New Tax Cuts-The Distributional Impacts of Repealing Dividend Taxation (Brian Roach, February 2003)

03-02 Macroeconomics for the $21^{\text {st }}$ Century (Neva R. Goodwin, February 2003)

03-03 Reconciling Growth and the Environment (Jonathan M. Harris and Neva R. Goodwin, March 2003)

03-04 Current Economic Conditions in Myanmar and Options for Sustainable Growth (David Dapice, May 2003)

03-05 Economic Reform, Energy, and Development: The Case of Mexican Manufacturing (Francisco Aguayo and Kevin P. Gallagher, July 2003)

03-06 Free Trade, Corn, and the Environment: Environmental Impacts of US-Mexico Corn Trade Under NAFTA

03-07 Five Kinds of Capital: Useful Concepts for Sustainable Development (Neva R. Goodwin, September 2003)

03-08 International Trade and Air Pollution: The Economic Costs of Air Emissions from Waterborne Commerce Vessels in the United States (Kevin P. Gallagher and Robin Taylor, September 2003)

03-09 Costs of Preventable Childhood Illness: The Price We Pay for Pollution (Rachel Massey and Frank Ackerman, September 2003)

03-10 Progressive and Regressive Taxation in the United States: Who's Really Paying (and Not Paying) their Fair Share? (Brian Roach, October 2003)

03-11 Clocks, Creation, and Clarity: Insights on Ethics and Economics from a Feminist Perspective (Julie A. Nelson, October 2003)

04-01 Beyond Small-Is-Beautiful: A Buddhist and Feminist Analysis of Ethics and Business (Julie A. Nelson, January 2004)

04-02 The Paradox of Agricultural Subsidies: Measurement Issues, Agricultural Dumping, and Policy Reform (Timothy A. Wise, February 2004)

04-03 Is Economics a Natural Science? (Julie Nelson, March 2004)

05-01 The Shrinking Gains from Trade: A Critical Assessment of Doha Round Projections (Frank Ackerman, October 2005)

05-02 Understanding the Farm Problem: Six Common Errors in Presenting Farm Statistics (Timothy A. Wise, March 2005)

05-03 Securing Social Security: Sensitivity to Economic Assumptions and Analysis of Policy Options (Brian Roach and Frank Ackerman, May 2005)

05-04 Rationality and Humanity: A View from Feminist Economics (Julie A. Nelson, May 2005)

05-05 Teaching Ecological and Feminist Economics in the Principles Course (Julie A. Nelson and Neva Goodwin, June 2005)

05-06 Policy Space for Development in the WTO and Beyond: The Case of Intellectual Property Rights (Ken Shadlen, November 2005)

05-07 Identifying the Real Winners from U.S. Agricultural Policies (Timothy A. Wise, December 2005)

06-01 The Missing Links between Foreign Investment and Development: Lessons from Costa Rica and Mexico (Eva A. Paus and Kevin P. Gallagher, February 2006)

06-02 The Unbearable Lightness of Regulatory Costs (Frank Ackerman, February 2006) 
06-03 Feeding the Factory Farm: Implicit Subsidies to the Broiler Chicken Industry (Elanor Starmer, Aimee Witteman and Timothy A. Wise, June 2006)

06-04 Ethics and International Debt: A View from Feminist Economics (Julie A. Nelson, August 2006)

06-05 Can Climate Change Save Lives? (Frank Ackerman and Elizabeth Stanton, September 2006)

06-06 European Chemical Policy and the United States: The Impacts of REACH (Frank Ackerman, Elizabeth Stanton and Rachel Massey, September 2006)

06-07 The Economics of Inaction on Climate Change: A Sensitivity Analysis (Frank Ackerman and Ian J. Finlayson, October 2006)

07-01 Policy Space for Mexican Maize: Protecting Agro-biodiversity by Promoting Rural Livelihoods (Timothy A. Wise, February 2007)

07-02 Declining Poverty in Latin America? A Critical Analysis of New Estimates by International Institutions (Ann Helwege and Melissa B.L. Birch, September 2007)

07-03 Economists, Value Judgments, and Climate Change: A View From Feminist Economics (Julie A. Nelson, October 2007)

07-04 Living High on the Hog: Factory Farms, Federal Policy, and the Structural Transformation of Swine Production (Elanor Starmer and Timothy A. Wise, December 2007)

07-05 The Politics of Patents and Drugs in Brazil and Mexico: The Industrial Bases of Health Activism (Ken Shadlen, December 2007)

08-01 An Overview of Climate Change: What does it mean for our way of life? What is the best future we can hope for? (Neva Goodwin, March 2008)

08-02 Ecological Macroeconomics: Consumption, Investment, and Climate Change (Jonathan Harris, July 2008)

08-03 Policies for Funding a Response to Climate Change (Brian Roach, July 2008)

09-01 Resources, Rules and International Political Economy: The Politics of Development in the WTO (Kenneth C. Shadlen, January 2009) 